\title{
4. わが社の映像情報メディアへの取組み
}

企業, 四体の技術香職を代表するち々に、をの立場 から: 映像情報メディアの将来方ととれぞれの取 組みを語っていただきました。

なお，揭載順は氏名のアイウエオ順とさせていただ きました

\section{個人の情報化時代に向けて}

映像情報メディアがテレビジョンの枠を越えて, 通信やコン ピュータの世界に広がり始めた。近年急速に進歩した LSI 技 術が映像情報の圧縮技術と伝送技術に革新をもたらし，放送分 野と通信分野を問わず安価な手段で高品質の映像情報伝送を可 能とした。多チャンネル化により情報選択の範囲が広がり, 通 信機能と結合して能動的な情報収集や個人レベルでの映像情報 の発信も容易になりつつある。

新 本 孫 宏 シャープ株式会社 専務取締役 技術本部長

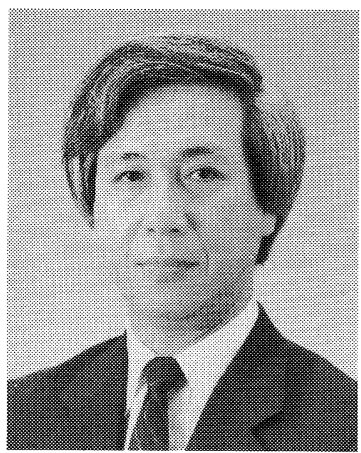

当社は放送受信機や通信端未分野の事業に永年取り組む一方，個人の情報発信を支援する新しい形のビデオカメラやネ ットワークに接続できる携带情報端末などを積極的に提案し，一定の評価を得てきた。最近では，テレビ受信機能とネッ トワーク機能を統合した製品を発表している．複数の情報源から望みの情報が入手しやすくなるとともに，自らも情報を 発信したいとする意欲を喚起するものと期待している.

21 世紀のキーワードは「ディジタル」，「ネットワーク」，「サービス」となり，ディジタル AV は家庭の姿を大きく 変える原動力となると予想される，そこではテレビも通信端末も，そしてコンピュータも区別がつかなくなる．家庭の機 器, そして, 携帯情報機器がすべてディジタル化され，相互接続されたとき，人々が追い求めていた “各個人が世界中の 情報を，いつでも好きなときに，欲しい情報だけを選択・入手し，加工蓄積できるとともに，共感できる相手に自由に発 信できる”夢の時代が到来すると期待している。

このような夢を実現するためには, 関連要素技術開発, 特徴ある新規デバイスの創出, 使いやすさを実現するソフトウ エア技術開発などの推進が，これまで以上に重要となる。また，個人の必要性や喷好に合い魅力的な新規サービスの創出 も課題である。ささに，標準化への取り組みも重要性を増し，多方面と協力して進めていきたいと考えている.

(1996 年 10 月 1 日受付) 


\section{ディジタルビデオ技術の研究開発}

テキサスインスツルメンツ筑波研究開発センター(略称 TRDC) は，本社をテキサス州ダラスに置くテキサスインスッ ルメンツ (TI) 社の $100 \%$ 子会社で, 研究開発をその業務として いる. ダラスには半導体グループの下に 4 つの研究センターが あり, お互いに協力して半導体や情報技術の研究開発を行って いる。ここでは TRDCを中心として，TI 社の映像情報技術の 研究開発戦略について簡単に述べる.

\section{生 駒 俊 明}

株式会社テキサスインス ツルメンツ 筑波研究開発センター 代表取締役 社長

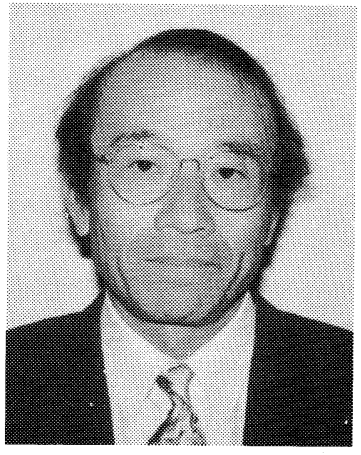

TI は半導体チップメーカとして有名であるが, 現在ではシステムチップ化を反映して, システム技術的な研究開発を 重視している. 特にディジタル信号処理に関しては早くから研究開発を進め, 現在ではDSP 市場のほぼ $40 \%$ を占めるシ エアをもっている. TI 社のモットーは顧客の要望に応えてDSPソリューションを提供することにある. マルチメディ ア時代には複雑な信号処理が随所要求されるが，なかでも画像は非常に情報量が多く, 人間の知覚の中で最も基本的な 情報源のひとつである．TIでは画像情報を処理するための様々な技術開発を行っている．すでにマルチメディア映像用 DSP として MVP (C 80) を市場に投入しており，これにより高度に複雑な画像情報処理が可能となっている. 現在さらに この上位チップを開発中である.

画像情報処理の中で最も重要な技術のひとつは圧縮伸長技術である．TRDCではディジタルビデオ用の圧縮技術を世 界に先駆けて開発，世界標準に準拠した MPEG-2 技術を完成させた。これをもとに 525 インタレース，525プログレッ シブ規格の実時間エンコーダを製造し，日本テレビ放送網(株)との協力により，525 プログレッシブディジタル放送シス テムのフィールドテストに成功した。現在はディジタルワイドピクチャフォーラムの一員として, 日本の次世代ディジタ ルテレビ規格の検討に積極的に参加している。 また画像伝達技術についても, 各種変調方式に対応したシステム開発をダ ラスの研究グループと協力して進めている．このような技術を基にしてチップセットの開発を行い，セットメーカに提供 していく計画である. また, 次世代の圧縮技術である MPEG-4 に関する研究も進めており, 標準委員会にも積極的に貢 献している，同時に, 将来のディジタルテレビに向けた技術開発も行っており, 圧縮伸長技術に加えて, 画質を改善する いろいろなアルゴリズムの研究, また高精細高画質テレビにむけての大容量の情報の記録なども研究の視野に入れてい る.

TI は顧客のニーズに応え, ソフトを含めた DSP を提供できるように，いろいろな信号処理技術の研究開発を行って いるが, その中でもディジタルビデオを最も重要な技術のひとつと位置づけている.

(1996 年 10 月 18 日受付) 


\section{わが社の映像メディア戦略}

このたび, 貴学会が「映像情報メディア学会」と改名される ことについては，くしくも「Imaging \& Information」を社の CI としている弊社としても非常に慶ばしいことである.最近 は日常的に, ディジ夕ル時代あるいはマルチメディア時代と呼 ばれているが，そのコンテンツの中枢を占めるのが映像情報で あり，その情報量の豊富さ，また多様さ故に映像情報は今後ま すます重要な位置を占めるものと考えている。

弊社は銀塩写真フィルムおよよ゙゙印画紙という 150 年の歴史を 持つ映像情報を記録また再現するメディアを長年製造してきている，写真は最も古くかつ一般に定着した映像メディアで ある。それは，これだけの高画質の映像が，手軽に安価に入手できるシステムは今日に至るまで存在しなかったことによ る. 同様にテレビジョンも, 一般家庭における映像情報の唯一の手軽な視聴手段として茶の間に君臨してきた。両者は単 なる技術の域を超え，写真文化，テレビ文化という言葉が示すように，社会になくてはなら存在である。

現在のディジタル化, マルチメディア化の急速な流れの中で, 両文化をひとつの映像情報という切り口で再定義し, 新 しい文化に発展させることが, 今までこの両文化を支えてきた者の義務ではないかと考光る.

弊社では, 手軽な記録手段としての写真フィルムからディジタル画像への変換技術, 写真画質のハードコピー技術, デ イジタルカメラに代表される高精細な撮像技術，正しい色再現を実現するカラーマネージメント技術を核として，コンピ ュータ等の他分野の技術との融合で新世代の映像メディアの創造をめざしている。また，一般家庭において手軽に写真を テレビ画面上で楽しんでいただく「Fotojoy」を，新しい写真のアプリケーションとして提案している．本学会が次世代 の映像情報文化を担う技術と文化の創造の場として，今後の発展を祈念すると共に，弊社も微力ながら尽力したいと考え ている。

(1996 年 10 月 18 日受付)

\section{Imaging Innovation}

ディジタル技術の進展は, 映像情報機器へコンピュータ機能 の内蔵とそれぞれの機能の融合をもたらし, 静止画, 動画, テ キスト, CG, サウンド等, 映像情報メディアにおけるシーム レスなハンドリングを可能とした．またinternet の急速な普 及は，あらゆる技術，製品，事業のボーダレス化と，それらの 融合・再構築を加速しつつある。このマルチメディアにおける 新たなソリューション創出と製品・事業分野の変革は, 映像入 出力, 画像処理, ヒューマンインタフェース, ネットワークな どの分野で, Imaging Innovation とも言引べき映像を主体とした技術変革により実現される.

キヤノンは, “世界一のカメラ”の創業以来, 光学・精密・プロセス・ディジタル信号処理などの技術をべースに, ビデ オカメラ, 複写機, LBP, 医療機, 放送機器, 半導体焼付装置など, コンシューマからオフィス, インダストリーの分 野で, 常に最高の映像と品質, 新たなソリューションの提供を目指してきた. BJ (バブルジェット) 技術による捺染シ ステムは, 独自技術を他の分野に融合し, 新たなソリューションの創造のみならず, 産業構造をも変革する一例として挙 げることができよう. Imaging Innovationは,このように映像・情報分野で幅広い得意技術を有するキヤノンが担うべ き最重要技術課題である. 具体的には,

（1）ディジタルカメラ，BJ プリンタ，高画質化技術による Photo Quality Print, ディジタル・ホーム・ラボ.

（2）入出力技術，画像処理技術，ネットワーク技術によりマルチメディア情報を統合するディジタルオフィス.

(3) $3 \mathrm{D}$ 撮像・表示, 高速通信技術等によるサイバースペースでの新映像表現, Interactive Image Creation. などであり，これら Imaging Innovationの成果は，「世の中になかった技術・商品を創り出す」，「他社の同様な技術 ジャンル, 商品ジャンルを尊重する」というキャノンの開発原則と「共生」の企業理念とを基に, 関連学会, 業界とのア ライアンスを展開し，マルチメディア時代のコアカンパニーをめざす.

(1996 年 10 月 14 日受付) 


\section{映像の花開くオフィス}

工場がものの生産の場であるならば，オフィスは知的創造の 場である.リコーはコピー機など映像を中核とするオフィス機 器によって, 効率的でかつ快適なオフィス環境の提供につとめ てきた。世界にさきがけてオフィスオートメーション(OA)を 提唱したのは 1975 年であった. それはオフィス機器の導入に よって，筆耕やトレースなどの単純作業から人間を解放し，よ り創造的活動に力をそそげるようにすることをめざしたもので あった. 爾来, 20 年を経てスタンドアロンの機器の導入によ る省力化, 自動化はほとんど達成された。しかし今はオフィスは新しい発展を迫られている。

海外展開, 国際協業, 遠隔勤務などによってオフィスの空間的拡がりは一挙に拡大した。ネットワークは地球のすみず みまで, またりモートオフィスやホームさらには移動中の車や航空機にまで, オフィス空間を延長しつつある. 組織は平 坦で分散的になり，一人一人の自主的創造的判断に基づいた業務の遂行が求められている。それには各人の生成，収集し た情報の全体的蓄積と効率的な再配分，表示を欠かすことができない。しかも，それは特別の訓練なしに万人が使いこな せるインタフェースをもつものでなくてはならない。それはまさに映像情報メディアの世界である。

リコーは長年培ってきた画像技術, ディジタルファクシミリやコピー機で先駆したネットワーク技術, 文字認識, 音声 合成など, これからのヒューマンインタフェースに重要な認識合成技術, 光ディスクなどの文字保管検索技術, フォント やリコースクリプトなどの文書表現技術, それらを統合するシステム技術など, 21 世紀のオフィスを実現する充分な備 えをもっている．従来オフィスとは別個の事業分野であったカメラもディジタルカメラの登場により，オフィスにおける 有力な入力機器になりつつある。 また地球社会の要請でもある省資源, 省エネルギ一, 無公害, 再利用についても画期的 なリサイクルコピー技術を開発している。

映像の花開くオフィス。それがリコーの目標である.

(1996 年 9 月 27 日受付)

\section{映像コミュニケーションの実現}

新年あけましておめでとうございます。新学会の益々のご発 展を期待しております.

さて, 貴学会がテレビジョン学会から「映像情報メディア学 会」に改組されたように, 弊社も 10 年前に東洋現像所から $\lceil\mathrm{IMAGICA}$ (イマジカ) へ社名を変えるとともに, 弊社の活 動指針を「映像コミュニケーション」の実現とし, 社会の動 き，技術の動向をより敏感にキャッチできるような体制づくり を常に心がけてきた。ご承知のように，10 年前というと 1960 年代に登場してきたビデオが 70 年代に普及し，フィルムに代わって主役になった時代であり，また一方で 3 次元のCG 映像制作技術がやっと出はじめてきた時代である，正直なところ，当社の基本活動指針を「映像コミュニケーション」と 定めたものの，漠然とした指針ではあった。しかし今は，その後のコンピュータの普及，そして映像のディジタル化とい う流れが非常に速いスピードで進展しており，本号の特集にもあるように，さまざまな角度から「映像情報メディア」が 現実論として論じられる時代，まさに「映像コミュニケーション」の時代の到来といえるのではなかろうか.

今日現在，弊社の「映像コミュニケーション」の意味するところは，(1) 見たことがない映像を提供できる体制づくり， (2) 見たい映像をいつでもどこでも見られる体制づくり，(3) 知りたいことをいつでもどこでも提供できる体制づくり，(4) 様々な情報を「視覚化」することで，より正確なより豊かな情報として提供できる体制づくり，であると認識している． 今後の社会や技術の進歩に伴い，「映像コミュニケーション」の意味するところは変化していきつづけるであろが，弊社 の活動の基本指針とする「映像コミュニケーション」の実現という姿勢は，将来にわたつて弊社のキーワードとなるだろ うと考える。また，このキーワードを弊社活動の中に反映させていくためのべースとして「技術」を位置づけている．特 にフィルムおよびビデオの映像処理技術，映像ディジタル化技術，コンピュータ技術そしてソフト(コンテンツ)に対する クリエイティブカを中核の技術としていきたいと考えている.

(1996 年 9 月 30 日受付) 


\section{「儲けよう」「何でもやろう」 ーテレビ朝日のメディア戦略一}

「学会」がその名称を変更しようという主旨と同様に, テレ ビ朝日のメディア担当局は衛星放送室, メディア開発局, そし て「マルチメディア局」と 3 年のうちに目まぐるしく局名を変 えてきた．メディアが持つ宿命か，時代の反映か，いずれにし てもいっときの息も抜けない現状である.

「戦略」などというほど大層なことではないが，わがマルチ メディア局発足の企図には，こうした現在のメディア状況にわ ずかでも追いついておきたいという社の狙いがあった，BS/

北 村 旬 右 全国朝日放送株式会社 マルチメディア局 局長

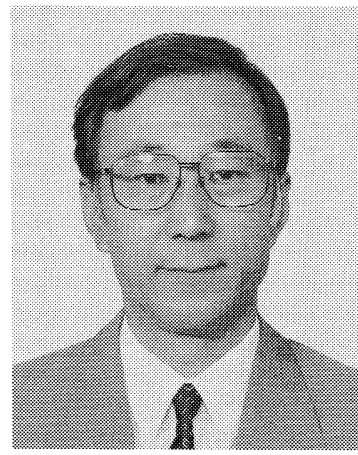

$\mathrm{CS}$ ，インターネットなどこれからのメディアについては業務部が, CD-ROM や商品化権はソフト事業部に, ハイビジョ ン制作部は地上波のワイド番組やVTR 制作の素材制作までを担当，そしてすべての著作権/放送権の掌握はライツ推進 部が——と，マルチメディア局内部で業務が完結できるような体制をまがりなりにも作ったのである。

そして 1 年一一各部の業務は, 部の垣根を越えはじめている. ライツ推進部が番組から生まれた玩具の商品化権獲得に 乗り出す，業務部がインターネットによる商品販売の可能性を探る, ソフト事業部がハイビジョン映像を CD-ROM 化す る。局全体の合言葉は，「儲けよう」となった。

とはいったものの，年間の収益はまだまだである，経理当局からは一応の評価が出てはいるが，これからの可能性充分 な事業を，われわれは“鵜の目鷹の目”で探している段階である。近久,デー夕放送を立ちあげる。「マンガサミット」 などのイベント事業にも，手を出した．番組ソフトの海外販売を，担当局を差し置いて促進しょうと試みている。もちろ ん, 今流行のショッピングについては, 率先して社内の旗振り役である.われわれの第二の合言葉は, 「何でもやってし まおう」となりつつある。しかし，わが社は「テレビ局」である。しかも地上波である。そろそろ足が地についた本格的 な戦略を，構築しなければならないと考えている。

(1996 年 10 月 2 日受付)

\section{凸版印刷の映像メディア戦略}

当社は印刷業として古くから写真技術を中心にしたカタロ グ, パンフレットなど印刷物の静止画を扱ってきたが，今から 約 13 年前に新しいビジネス領域としてビデオ(動画)制作を始 めたのがこの分野への参入のきっかけである. 当時は企業のセ ールスプロモーション用ビデオパッケージが主体であったが, その後, 画像の高精細化の流れにのってハイビジョン映像の企 画制作に着手し，イベントや美術館展示など映像ビジネスの領 域を次第に拡大していった。さらにこうした映像を取り入れ

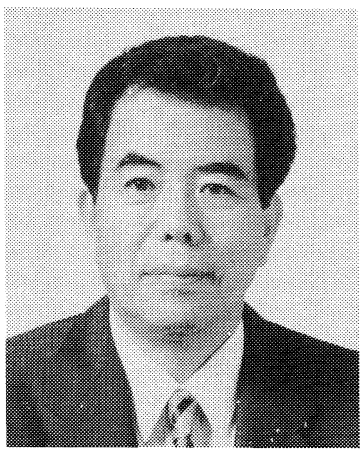

て, V-CD， CD-ROM などのパッケージの企画制作への展開をはかった.

ところでコンピュータネットのアプリケーションが, ビデオテックスからインターネットへと進展し，放送はVHF， UHF から衛星ディジタル多チャンネル放送の出現による多チャンネル化時代を迎えるにいたり，マルチメディア社会対 応の戦略を進めつつある.ディジタル化をキーワードに通信と放送の融合が進むと, すべての映像情報メディアは一部企 業の独占から利用者の共有のものとして変化していくと考えられる．この時, 映像コンテンツの配信は質的にも量的にも 重要なキーを担うことになろう，当社は他社にさきがけ，昨年映像・音声を含めたフルディジタルの編集センターを開設 した。この意図はディジタルコンテンツのプロパイダとしての地位を確立することにある．この編集センターを利用して すでに MX-TV, テレビ東京, パーフェク TV などの番組制作を手掛けはじめた。

ディジタル映像はコンピュータネットワークやディジタル放送だけでなく，その他のディジタルメディア (CD-ROM, DVD など）にも展開可能である。映像のディジタルコンテンツを種々なメディアに展開していく，いわゆるワンソー ス・マルチユースが当社の戦略である.

(1996 年 10 月 28 日受付) 


\section{インターテキストで無線系マルチメディア への第一歩}

高度情報時代は，コンピュータによる産業の情報化から，現 在は国民の生活文化の情報化へと進んできた。また，ディジ夕 ル技術の急速な進歩や規制緩和によるテレビの多チャンネル化 など, 放送事業者をとりまく環境は，21 世紀に向かって大き く変わりつつある。

そして，多種多様の情報をわかりやすく伝達することができ る映像情報の役割がますます高くなり, テレビ事業者はその役 割を大きく担っていく必要がある。現在まで民放局は，主とし

黒 田哲 也 株式会社テレビ東京 取締役 メディア担当

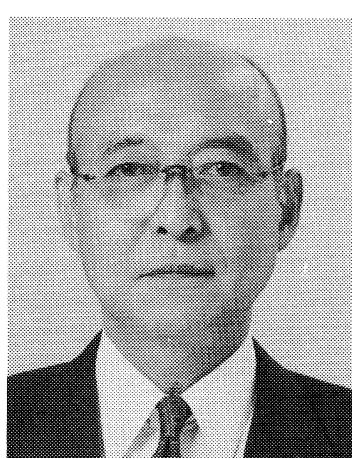
て広告収入により経営の基盤を築いて発展してきたが, 多メディア・多チャンネル時代になると, 従来の広告収入は必然 的にシェアダウンを余儀なくされるのは明白である。多様化する視聴者のニーズに対応するため, 永年にわたり培ってき た制作力を活かして良質の映像ソフトを制作するなど，媒体力の向上を図ることはいうまでもないが，同時に映像ソフト を軸としたマルチメディア戦略による事業の多角化を推進することが, これからの映像情報産業における放送事業者の浮 沈を決めることにつながるともいえる。最近は「インターネット」の文字が新聞紙面を賑わせているが, まだまだパソコ ンユーザを中心とした人々のみでの現象ではないかと考える.

テレビ東京では, 日本のほぼ全世帯の茶の間に普及しているテレビ受像機を軸とした無線系マルチメディアサービスの 第一歩として, 1996 年 10 月から VBI 方式による地上波データ多重放送「インターテキスト」を開始し, 地上波テレビ 番組の画面に扔ける双方向性を初めて実現した。この放送は, 現時点で利用可能な限られた技術を使ってスタートしたも ので, 機能的には不充分な点が多い.しかし, これを将来に向かっての現在の取り組みとし, 今後のさらなる技術の進展 で可能となる放送の高・多機能化や，マルチメディアサービスの開発につなげて行くことを目的としている. 将来は, テ レビ映像とともにマルチメディアサービスの地上波による地域展開と, BS 波による全国展開を行う高度情報社会の中核 的メディアとして発展させていきたい。

\section{三洋電機のマルチメディアへの取組み}

映像情報メディア分野では，LSI プロセスの進歩による「シ ステムオンチップ」化と MPEG など，映像等に関する規格化 の前進, コンピュータソフトの進展やインターネットに象徴さ れるネットワークの発展による新しい時代へのパラダイムシフ トが進んでいる。いうならば「ディジタルレボリューション」 つまり「ディジタル鞈」が来つつある。

当社は，このような最先端技術の研究開発をベースにディジ 夕ル映像，立体映像技術など当社の特長を生功て，利便性に

桑 野 幸 徳 三洋電機株式会社 常務取締役 研究開発本部長

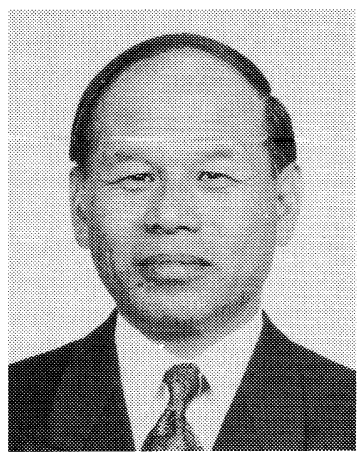

加え「興奮と感動」を呼び起こす「人にやさしいマルチメディア」の提供を目指している.

液晶ディスプレイ技術を応用した $3 \mathrm{D}$ （立体）映像システムがその代表例である。これは特殊なメガネを使わなくても $3 \mathrm{D}$ 映像を楽しめるもので, 1994 年に $3 \mathrm{D}$ 映像システムとして発売した。また, 1995 年に世界で初めて家庭用立体テレ ビも発売した。当社のマルチメディアへの取り組みは, 次の 3 つの柱からなる.

まず第 1 に, マルチメディアの心臟部となる基幹部品事業の推進である. 当社は, DVD 用 $635 \mathrm{~nm}$ 短波長レーザや次 世代の低温ポリシリコン LCD の開発・事業化に世界で最初に成功した。 システム LSI, 小型 2 次電池でも世界をリード している.第 2 に, 新技術による既存商品のマルチメディア化も重要と考えている.さらに第 3 に，今までにない新しい マルチメディア事業の推進が上げられる。最近発売したインターネットTV は家庭で一般の人がインターネットを手軽 に楽しめる. PHS 携帯電話, FM 多重放送, ディジタルスチルカメラ, ディジタルテレビ等, 続々と家庭にディジタル の波が押し寄せ，それがネットワーク化され，私達の生活は激変していくであろう．まさしく，21 世紀は家庭で，オフ イスで，地域で，ディジタル映像情報メディアが生活の基本を支える時代になるであろう.

(1996 年 9 月 20 日受付) 


\section{郵政省の映像情報メディア技術政策 一マルチメディア時代に向けた放送技術政策一}

放送は国民に広く普及した基本的な情報メディアのひとつで あり，特にテレビは映像情報を一度に多くの人久に対して容易 に提供することが可能なメディアとして，今後のマルチメディ ア時代においても引き続き重要な社会的役割を果たすものと期 待されている，昨今このテレビを取り巻く環境が急激に変化し つつあり, 行政も変化の可能性を的確に把握し，タイムリーに 適切な政策を打ち出すことが求められている.

小林 郵政省放送行政局 放送技術政策課 課長

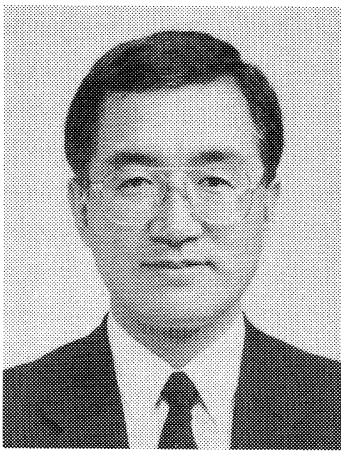

ディジタル技術の発達により，米国では衛星を用いた 100 チャンネル以上のディジタル多チャンネル放送が急成長を遂 げ，日本でも通信衛星を用いて同様のサービスが開始された。テレビジョン多重放送においては文字多重放送に加えてデ 一夕多重放送が制度化され，衛星放送扔よび地上放送において多種多様なディジタル情報の提供が開始されている。ま た, CATV や地上放送のディジタル化, 放送衛星によるディジタル HDTV の開始に向け, 技術開発, 制度面の検討な どの諸準備が着々と進められている。こうした放送の高度化・多様化に加え，インターネットテレビなど様々な面で通信 と放送の融合が確実にかつ急速に進展している。

こうした変革期において適切な行政を行うため, 郵政省は「放送高度化ビジョン」をとりまとめ, 2010 年の放送の将 来像とそこに至る道筋を推定した。また，「西暦 2000 年までの情報通信高度化中期計画」では放送ネットワークのディ ジタル化の高度化目標として, 都市型 CATV 施設の 10〜20\%のディジタル化および 2000 年から 2005 年までの地上ディ ジタル放送の導入を揭げた。放送関連技術の研究開発に関しては，「研究開発基本計画」において，次世代放送方式，統 合ディジタル放送，双方向型放送，インテリジェント放送端末，地上ディジタルネットワーク技術，種々のコンテント支 援技術の開発などを重点開発プロジェクトとして提示した．また，「マルチメディア時代に向けた放送技術の将来展望」 においては，今後の放送技術の目指すべき方向として，知的で，多機能な，多種・多彩な情報を自在に享受できる技術一 IMPACT (Intelligence, Multi-Performance, Active-Content Technology) を提唱し，放送技術，コンテント制作技術お よび端末技術について目標を設定した．2010 年の目標の具体イメージとして，2000 TV 本レベルの放送，ソフトウェア による放送方式の変更, 立体映像, 100 インチ程度の超薄型軽量ディスプレイ, シナリオから映像情報へのリアルタイム 変換, 高機能 $\mathrm{CG}$, 言語のリアルタイム翻訳，高齢者支援などの技術の確立を掲げている.

郵政省は，世界的視点からこうした政策目標を掲げ，産学官連携の推進体制の下で諸施策を展開している.

(1996 年 10 月 2 日受付) 


\section{映像情報メディアの価値連鎖}

昨年の初めから，垂直帰線期間(VBI)を利用したデー夕多重 放送のいろいろな応用が考えられている.10月からは, テレ ビ東京から，文字放送と共存するかたちでインタラクティブ情 報画像を送る IT ビジョンの放送が始まった．これは, 放送各 社, テレビメーカ, NTT, サービス提供各社などが進めてき たインターテキスト方式のデータ多重放送である. 文字放送で は, 情報となる文字のストリームを伝送するのであるが, イン ターテキスト方式では，「アクティブ・コンテンツ」と表現し

小見山 株式会社東芝 Advanced-I 事業本部長

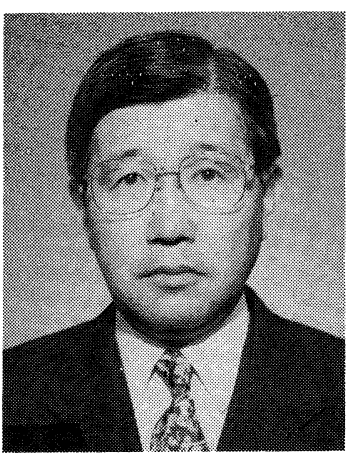
てよいかと思うが, 送る情報はコンピュータプログラムを含み, これをテレビ内のコンピュータが解釈して, インタラク ティブな画像を表示するものである。テレビを見た視聴者から，フィードバックがある場合は，テレビに内蔵されたモデ ムから電話線を介して, データがコンピュータに送られる仕組みにもなっている.ディジタル化という観点からみれば, これまでのテレビ放送の走査線のほんの一部だけを借りて, ディジタル化した情報を載せただけともいえるが，次のよう に，これからの映像情報メディアの実現に必要なエネーブリングテクノロジーの多くの要素が絡んでいる.

・情報画面を作るための制作ツール

・映像と情報を多重化し, 伝送するための送出システム

・テレビ受像機内でこの情報を処理するソフトウェア

・テレビからのデータを受信するサーバシステム

映像に追加された情報媒体といえば，シンプルな 2 次元グラフィックスだけなのであるが，放送局やサービス企業との 協力のなかで, 新しいコンテンツを創り出すには, 多くの努力が必要である。しかし, このコンテンツの蓄積を重ねれ ば，映像情報メディアとしての大きな資産になるものと思う。情報媒体のすべてをディジタル化したDVDの分野でも， 制作システム, 映像・音声のエンコーディングシステム, DVDの製版設備, DVD プレーヤ, インタラクティブスクリ プト，PC 応用などのシステムの開発，大容量のディジタルコンテンツの制作など，大きな投資が行われている．映像情 報メディア事業においても, 加速的に変化する周囲の条件のなかで, 製品だけに留まらず, 価值連鎖をカバーする戦略を 組み立てなければならないと考える。

(1996 年 12 月 16 日受付)

\section{コンテンツからシステムまで 感性マルチメディア}

感性マルチメディアをめざして 当社は音楽・映像のソフ ト・ハード両面で高音質・高画質をキーワードしながら, 人久 に安らぎと潤いを提供すると共に, 多くの新しいシステム, 方 式, メディア等の開発を通して, いわゆる音楽・映像文化の発 展に寄与してきたと自負している. 昨今, 通信を含む衛星放送 やネットワーク関連インフラも着々と整備されつつあり, 近い 将来家庭も個人も含めて様々な場面でこれらの恩恵に浴するこ

佐々木 弘 忠 日本ビクタ一株式会社 専務取締役 技術開発本部長

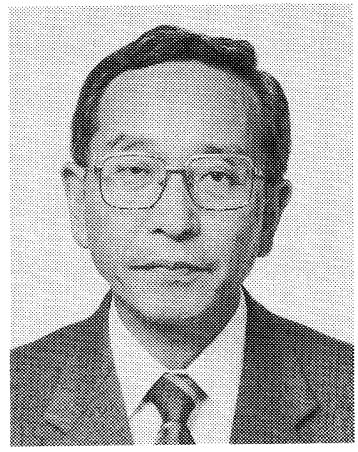
とになるが，重要なことは“対象は人”ということである。映像や音楽，文字や言葉を単に情報と捉えるだけでなく感情 や意志, いわば感性の表現と考えると, 当社は AV と感性技術で「人と人とのコミニュケーション」のお手伝いをさせ ていただいているといえる。このような観点で見ると, コンテンツとその制作環境, 媒体や伝達経路, 最終的に人とのイ ンタフェースとなる AV 機器等がコミュニケーションの意志を充分に反映できるものへと昇華させていく必要がある.

よりヒューマンな新ディジタル技術に期待 当社のILAによる新大型高精細映像システムやサーバとしての大きな可 能性を持つD-VHS, DVD，コンテンツを含む通信サービス等は「人と人とのコミニュケーション」をより快適にとい う考え方に基づいたひとつの提案である．一方，当社は早くから圧縮技術をマルチメディアの基本技術に位置づけ研究開 発に着手, MPEG 標準化にも多大の貢献をすると共に, 事業においても多方面に展開してきた。今後は, より高画質を 目指すとUDTV（ULTRA DEFINITION）等の世界も考えられる．圧縮をべースにした新ディジタル技術は種々のメデ イア融合をはかりながら進歩も早い。人間の特性でもあるアナログ性も大切に, 認識やヒューマンインタフェース, コン テンツ等を加え, 感性にまで踏み込んだ研究・開発を大切にしたい.

(1996 年 10 月 9 日受付) 


\section{わが社の映像情報メディア戦略}

「人にやさしく心地良い形に情報を加エし，最適なメディア を通してコミュニケーションする環境づくりをサポートする」 紙とインキの印刷業と映像情報メディアのイメージは一致しに くいかもしれないが, ビジュアル表現のノウハウを駆使して取 り組むテーマは同じといえるであろう。実際に印刷会社が映像 情報メディアを扱いはじめた歴史は古く，そこには 15 世紀以 来の「印刷」で培われてきた表現技法が数多く盛り込まれてい る. HD グラフィックスに代表される HDTV の高精細な静止

佐 藤 政一 大日本印刷株式会社 取締役

ACS 事業部長

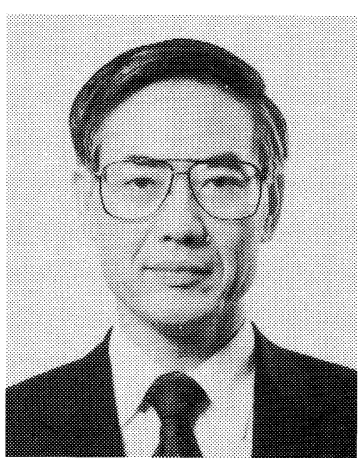
画表現にも，印刷の技術が基盤として生きている。印刷用スキャナで取り込んだ精度の高い画像に対し，表示内容に合わ せて色調やレイアウトを整えていく技術は，HD 静止画に欠かせないものである．また， CD-ROM 等のパッケージ系， インターネット等の有線系ネットワーク, ディジタル衛星通信等の無線系ネットワークなどのコミュニケーション手段の 拡大に伴い,メディアに合わせて最適なビジュアル表現の手法をそのつど蓄積し活用してきた。特に，マルチメラ゙ィアコ ンテンツの企画・制作には動画・音声の要素が不可欠であり，映像と印刷に関する技術やノウハウの融合はますます重要 となるであろう。

1997 年秋にスタートする衛星多チャンネル放送 DirecTV にはDNP も様々な形で参画し, 新たな情報メディアとして ユーザにアプローチしていく．DNP は冒頭のテーマを使命と考えて様々なメディアへの取り組みを積極的に推進してい く、今, インフォメーションテクノロジーの急激な進歩から, 企業や生活者を結びつける新しいコミュニケーションスタ イルが生まれようとしている，その道具として映像情報メディアを含めた様々なメディアを有効に使いこなす智恵が求め られている. DNP は「情報コミュニケーション産業」としての使命と責任を自覚し, 社会の求める情報の伝達と, その クオリティを高める技術の開発に努め, 新しい情報文化の創造の扔役に立ちたいと考えている.

(1996 年 10 月 17 日受付)

\section{映像情報メディアを活用したコミュニ ケーションの実現をめざして}

21 世紀の新しい, 通信・コミュニケーションのための基本 技術を研究するのが ATR 全体のミッションである。その中で 映像情報の持つ意味は大きい. テレビ会議やインターネットを 介した通信が一般化しつつあるが，まだまだ通信は音声・文字 メディアによるコミュニケーションが一般的である。いわば言 語メディアを用いた通信といっていい.

しかしながら, 映像情報メディアは言葉だけでは伝達が困難 である情報を容易に伝達できる可能性を持っている，考えてみ

酒 井 保 良 株式会社国際電気通信基 礎技術研究所 (ATR) 代表取締役 副社長

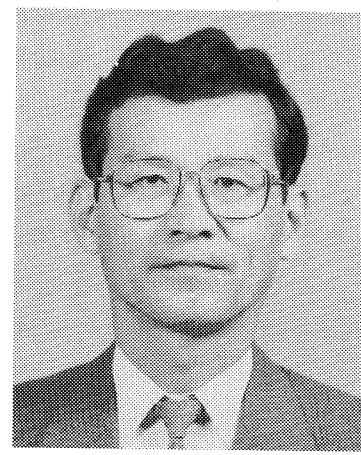
ると, コミュニケーションとは人間が頭の中に持っているイメージ・概念を相互に伝えあうことである. 通常のコミュニ ケーションでは言葉を用いてこれを行っているが, 風景, デザインなどは言葉では表現困難である. このような場合に絵 や図で表現しようとしても, 素人は表現能力が不足しているため充分表現できないという場合が多い。一方, 例えば画家 などのアーティストは, 絵画などの手段を用いてイメージ・概念などを相手に伝える能力に優れている.このような能力 は一般の人の中にもあるはずであるが, 我々は言語によるコミュニケーションにあまりにも依存しているために，この能 力を生かすことができていないと考えられる.コンピュータで支援することにより, だれでも頭の中のイメージを容易に 表現できるようにならないだろうか.これが実現できれば, 従来の言語メディアに加え映像情報メディアを活用した新し いコミュニケーションの可能性が開けてくる.これを実現しようとする研究, すなわち「イメージ表現技術」をひとつの 大きな柱として研究を進める予定である.

そのための具体的なアプローチとして, アーティストと工学者の共同研究を提唱している.アーティスト, 特に映像関 係のアーティストは, イメージを言語以外の手段で表現できる能力に優れている. 工学者とこれらのアーティストが共同 研究することにより, 工学者はアーティストのノウハウを取り入れたシステムの構築をめざし, アーティストはこれを初 期の段階から使うことにより，真に使いやすいシステムを作り上げて行きたいと考えている.

(1996 年 10 月 27 日受付) 


\section{デジタルコンテンツ制作からデジタル配信へ}

1990 年代初期からの音声を含む映像データのディジタル化 に伴い, ひとつの映像情報を, テレビ, 映画, インターネット CD-ROM，ゲーム等の複数のメディアへ展開できるようにな つた。いわゆるディジタル(マルチ)メディア時代である.シリ コングラフィックス（Silicon Graphics, Inc., 以下 SGI）は, コンピュータグラフィックス技術を中心に, オーディオ, ビデ 才等をいち早くコンピュータに取り入れることにより，ディジ タルメディアにおけるスタンダードとも言えるコンピュータハ ードウェアメーカとして最先端の技術を提供してきた．ご存知

杉 本 孝 浩

日本シリコングラフィッ クス・クレイ株式会社 企画本部

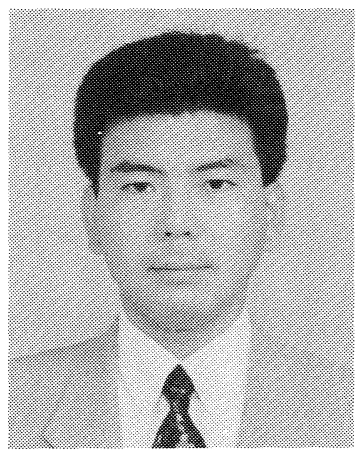

のとおり，最近のテレビコマーシャルや番組タイトルで映し出される CG 映像のほとんどが SGI のハードウェアで制作 されているが, SGI は数年前から CG とビデオおよび実写映像を融合させ，ペイント，特殊効果，ノンリニア合成/編集 等の処理を沉用 UNIX コンピュータで実現できることを可能にした. 近年話題となっているディジタル処理映像はSGI のハードウェア上で制作された作品である.

1990 年代前半をコンテンツクリエーションのディジタル化時代とすると, 1990 年代後半に映像情報メディアにおいて 要求されるのは, ディジタルコンテンツの配信および, 放送のディジタル化である.インターネットもその一つであり, 1996 年から開始された CS ディジタル放送は, まさにディジタル化ならではの帯域圧縮技術による多チャンネル放送を 可能にしている.そして今後の放送局内のディジタル化は必要不可欠であり, 映像を送出する機器もコンピュータベース のメディアサーバへと置き換わってくるであろう. また，メディアサーバの技術は放送局だけでなく，インターネットや イントラネットが普及していく中で, 企業や学校, その他の機関でも必要とされるであろう.八イクオリティな映像デー 夕から圧縮データまでを扱うために, メディアサーバには, CPU 処理性能, 内部バス転送速度, ディスク I/O, ネット ワーク等, 各々が高速でバランスのとれたコンピュータハードウェアが必要とされ, 要求に応じたスケーラビリティや配 信するためのソフトウェア技術が必要である.

SGI は 1996 年後に発表した革新的なハードウェアアーキテクチャをプラットフォームに, タイムワーナー, NTT と の共同実験を通して蓄積した配信ソフトウェア技術を中心に，メディアサーバテクノロジーを新たに提供することによ り，ディジタルコンテンツ制作から配信，放送までの総合的なりリューションを映像情報メディアに対し提供していく. (1996 年 10 月 26 日受付)

\section{家庭内マルチメディアシステムに最適な プラズマディスプレイ}

世の中は，マルチメディア時代へと入りつつある．関連する インフラも徐々に整備され, 近未来の家庭内マルチメディアが どのような形態で落ち着くかが明らかになってきた．この家庭 内マルチメディアシステムの中で, ディスプレイがどのような 位置を占めるであろうか. 今, 開発されている技術を基に予想 を立ててみた。

マルチメディアについての定義，説明はいろいろあるようだ が, マルチメディアの全体構造は, 実はシンプルなものであ る。様々な情報がディスプレイの前に居ながらにして手に入る ツールと考えればよい. マルチメディアとは, 映像, 音声, コンピュータ等のあらゆる情報が, ディジタル技術をベース に統合的に処理され, 利用されるシステムである。家庭内のマルチメディアシステムとは, 多チャンネルの画像, 音声を 単に受け取れるだけでなく，インタラクティブ性をもつことが重要となる．ホームショッピング，ホームバンキング等が 可能となり，またインターネットへの接続等も提供できるシステムでなければらならない．このようなサービスを 1 つの 画面で同時に受けることができるためには, NTSCより高品質な表示能力を持つディスプレイが必要となってくる.

従来のマルチメディアは, パーソナルコンピュータの小型ディスプレイと有線, CD-ROM で発展してきたシステムと いえよう. 大型高品質ディスプレイと放送というメディアが加わって初めて家庭でも楽しめ, かつ役立つマルチメディア が誕生する. 時にハイビジョンを楽しみ, 時にマルチメディア的サービスを可能にするプラズマディスプレイが家庭のマ ルチメディアシステム, 言い換えれば将来の家庭用 AV 機器の中心となると予測できる.パイオニアは, このようなシ ステムを目標に, プラズマディスプレイ, DVD, ディジタル衛星受信端末などの技術開発を進めている.

(1996 年 11 月 27 日受付) 


\section{映像新時代に向けて}

わが国でテレビ放送が開始されて約 40 年が経過したが, 「ディジタル」の出現によってこれからの 40 年のテレビはコン ピュータの世界との融合を含めて技術面, サービス面, 経営形 態の諸面で大きく変質していくものと思われる.これからは一 般消費者の家庭内環境も「家庭内マルチメディアシステム」の 実現を含めて大きく変わって行こうとしている，また，情報の 送り手側(従来はテレビ放送局) に扔いても地上, 衛星, ケーブ

杉 森 吉 夫 日本テレビ放送網株式会社 常務取締役 技術局長

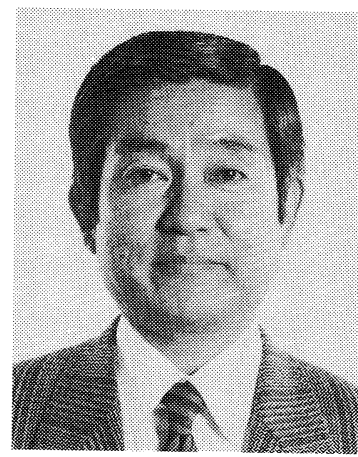

ル, さらに大容量の蓄積媒体をメディア横断的に把えた総合的かつ複合的なサービスの展開が可能となる。さらに，これ らのサービスはディジタル技術を中核とするマルチメディアとの融合になる奥行きと間口，ともに拡大されたものとして 進展することが期待されていると考えられる。

以上のような情報メディア環境を想定して私達はこれからの新時代は「改善」的な取組よりも「改革」的な取組みが， また業界での横並びよりも特色のアピールが今までのテレビ局に求められるようになるとの認識に立ちながら制作コンテ ンツの質, 量両面での充実やディジタル新技術で初めて可能となる新サービスの開拓を図るために新たな意味合でのコン テンツ制作体制，ネットワーク体制，ハードウェアシステムの整備強化に取組みたいと考えている．

これからの「映像情報メディア」の時代は「海図のない航海」の時代ともいわれるが, 私達は 40 数年前の我が国のテ レビ創業に深くかかわった一員としても，映像新時代の充実に向けて努力して行きたいと思っている。この時期において の学会の名称変更は, まさに時宣を得たものとして大いに歓迎したいと思う.

(1996 年 11 月 13 日受付)

\section{マルチメディア時代に向けてのソフト産業の在り方}

1990 年に入って, ディジタル化を中心とする技術革新の急 速な進展と衛星・光ケーブルなどの伝送媒体の拡大は, まさに メディアの多様化と拡張をもたらして来ており, 来る 21 世紀 は我々ソフト事業者にとって「マルチメディア時代のコンテン ツ(ソフト)産業の在り方」を答えなけ机ばならない時期と位置 づけている。これまでは，「地上テレビジョン放送」をメイン メディアとしてハード・ソフト一致のもとに放送産業を旗印と

関祥 行 株式会社フジテレビジョン 媒体開発次長

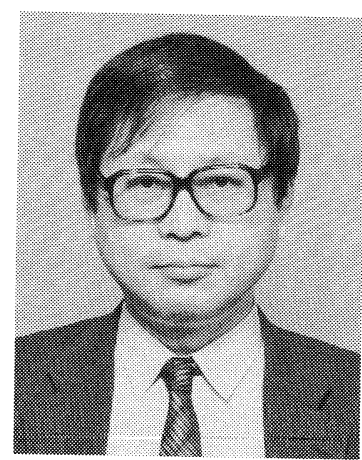

し, その派生としてパッケージメディア等に対応して来た。これからは, 地上波のみならず, 衛星放送, DVD を初めと するパッケージ系メディア, 通信系メディアに並行してソフトを供給し, ひとつの企業の中で垂直的多角化としての相互 のコンテンツ競争が激化して行くことになろう. 同時に, 水平多角化としての「ワンソース・マルチアウトレット」も活 発化して来るであろう。その時, 我々は「放送局」から「コンテンツ事業者」へと事業基盤が変質して行き，まさに「ソ フト制作・調達」能力が問われることになる.

そのための施策についてはソフト・ハード・組織等の観点から検討しているが，ここではハードとしての「HDTV」 について触れておきたい. HDTV は当面その第一次利用メディアは BS 衛星放送であるが, 一方でマルチメディア時代 を迎えて「ソフト素材」の重要性は益々高まり, ソフトの多元的利用 (マルチアウトレット), メディア変換（HDTV 制作 $\rightarrow$ フルム変換・配給等)，処理が盛んになって来ており，我が社でもすでに同様な映画製作を行って来た。そのよ うな多元的利用のためには，「ソフト原盤」の高品質化が望まれることから, 我が社の新社屋映像設備はトータル的に HDTV 制作が可能なシステムを基本としている.内容的に高い品位のソフトを高い画質で提供して行くことがコンテン ツ事業者の基盤であり，HDTVは 21 世紀の映像産業のベースであると位置づけている.

(1996 年 10 月 14 日受付) 


\section{富士通における映像情報メディア戦略}

世界のトップレベルのIT（インフォメーションテクノロジ 一）カンパニーを目指す当社にとって，映像情報メディアに関 連する技術は将来へ向けた重要な戦略技術である。ここでは, システム化技術とそれを支えるコア技術の両面から述べてみた い.

ディジタルネットワークは今後ますます重要度を増し，それ とともに，ネットワークを利用し映像情報メディアを駆使した

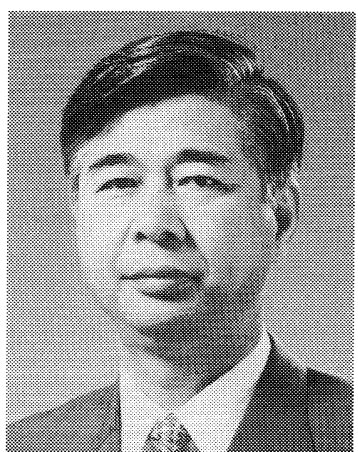

新しいサービスの提供が重要となる，超高速な Internet まで含めた幅広いネットワーク関連技術をバックボーンとし， その上で新しいサービスを展開していくために，映像メディアを取り入れた各種システム試行を積極的に進めてきた。例 えば, (1) MEDIA TOWER：映像を主体として, 放送, 新聞, 出版などのメディア情報を関連づけることで使い易くし た，企業向けの情報提供サービス，(2) Habitat II :ネットワーク上にビジュアルな対話空間を創出し，多くの人がゼス チャを交えた会話や，手紙・メモ・揭示板で情報のやり取りを行えるシステム，などである．

このような新しいサービスを試行する中で, システム化技術として，リアルタイム性を持徴とする映像メディアを扱え る，(1)データベースの構築と検索，(2)サーバ間連携，(3)コンテンツ制作支援，(4)ユーザ管理機能，を開発している.

一方，コア技術としては，(1) MPEG-2 に代表される動画像圧縮/伸長チップや 3 次元グラフィックス処理プロセッサ といった映像処理エンジン，(2)大型で高精度なディスプレイをCRT の約 $1 / 10$ の薄さで実現するプラズマディスプレイ (PDP)，(3)大容量記憶装置としての光磁気ディスク等について，低コスト化を意識した開発，を積極的に進めていく．

(1996 年 10 月 4 日受付)

\section{オンデマンド・プラットホームの実現}

マルチメディアの時代には利用者のニーズにタイムリーに応 えて必要な情報を提供する “オンデマンド”と可視化して情報 を伝える“ビジュアル”がキーワードになると考えられる.

NTTでは, 従来より静止画や動画の映像データベースシス テムを基本にオンデマンドの情報提供システムを開発し, 情報 案内, 商品流通, ビデオライブラリー, 医療などの幅広い分野 で個々の顧客にカスタマイズしたシステムを構築してきた. 最 近ではディジタルビデオオンデマンド (VOD)を開発し,
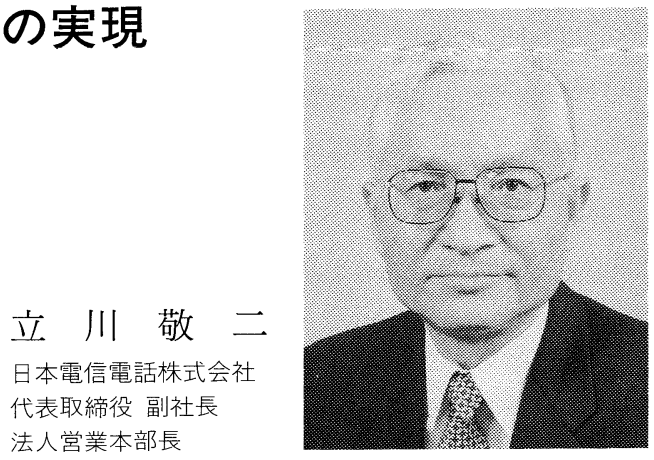

CATV 事業者などとの共同利用実験を始め, 各種研究機関などの先進的な取組や情報案内システム, ビデオライブラリ 一などの実現に笴与している。またテレビ会議の普及に努め, テレビ会議サービスの提供やテレビ会議装置の開発を行 い，最近ではパソコンにテレビ会議機能を付加したDTC(Desk Top Conference)を開発した. 今後, DAVIC(Digital Audio Visual Council) における国際標準化活動を積極的に推進し，VOD サービスの普及に努めるとともに，映像メディ ア特有の性質を利用した自動インデックス機能, 感性検索機能, テレビ会議機能との融合などヒューマンインタフェース の高度化を図り，よりインタラクティブで使いやすいマルチメディアオンデマンドシステムを実現していく．また， MPEG-2 エンコーダ, 大容量ファイル装置, 超高精細表示システムなどに代表される要素技術の開発を推進していく。

一方，ネットワークはISDN がパソコンの普及に合わせるように爆発的に需要が伸びており，低速ではあるがマルチ メディア情報の流通に一役かっている. 今後, インターネット型のコネクションレスサービスである OCN サービスや ATM 技術による広带域な専用線サービスを B-ISDN に先駆けて提供していく予定であり，イントラネットなどの企業 内(間)システムの構築やコンピュータ通信のいっそうの普及を支援していく．さらに，ATM をべースにした B-ISDN を構築し，21 世紀初頭には家庭への広带域サービスの提供を可能にしていくこととし，前述のアプリケーション, 要素 技術と合わせ高度化, 広帯域化を進め, 映像情報メディアが自由に流通し, 新しい情報産業の萌芽, 発展に寄与するオン デマンドのプラットホームを作っていく

(1996 年 10 月 2 日受付) 


\section{新 時 代に 対 応して}

21 世紀を目前に, 米国でのスーパーハイウエイ構想, 日本 での ISDB 等高度情報化社会が到来しつつある. 高度情報化 社会は情報の固有化, 双方化を可能にし, いながらにして仮想 現実体験が可能になる. 受動的であった情報の入手が, 能動的 に可能になり，地球規模で必要情報が即時に入手可能になる。 この高度情報化社会は映像信号処理のディジタル化により可能 となり, 情報処理・通信技術と融合して, 生活水準の大幅向上

丹治 忠男 三菱電機株式会社 常務取締役 映像情報事業本部長

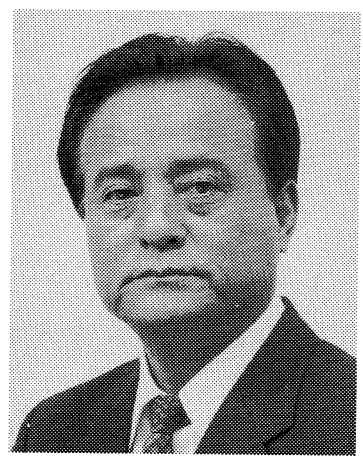
を可能にすると期待されている.

当社では，情報処理 (Computing), 通信技術 (Communication) とディジタル映像技術 (Visual)の融合 (CCV)をキーワ ードに事業展開を図っている．事業化上の課題はシステム化と新規キーデバイスの育成にあり，全社的連携のもとに開 発，事業化に取り組んでいる。事業分野別にその内容概略を以下に述べる.

\section{1. テレビ事業}

放送のディジタル化に対して，高画質多チャンネルおよび高機能サービス放送が企画され，受信機もディジタル圧縮， 変復調技術やインテリジェント化，インタラクティブ化に対応した IRD, STB の製品化に取り組んでいる。ディジタル TV 放送で先行する米国では, ルーセント社と受信機用 LSI チップセットの共同開発に着手, 欧州では規格標準になる DVB に対応するため, 放送機器メーカーの DMV 社とディジタル放送技術に関する共同開発を行っている. 国内では, インターネットテレビもいち早く市場に提案し, CCV の具現化に努めている.

\section{2. ディスプレイデバイス事業}

映像情報事業の基盤をなす戦略的に重要な分野である. 高輝度, 高精度展張マスク CRT の他, 新たに PDP の事業化 を推進し，1997 年度中には 40 インチ級テレビ用の量産体制を確立したい。

\section{3. ストレージ事業}

DVD は, 光ピックアップや LSI の強みを生かし, 今世紀最大の事業といわれる ROM ドライブやプレーヤの開発を行 っている。

\section{4. 映像情報システム事業}

当社の得意とする大型ディスプレイを武器に，屋外用オーロラビジョンや大画面 AV の表示システムを LED や液晶プ ロジェクタで実現, 更に高輝度化する.またテレビ会議システムや監視システムなどのニーズもますます増加, 多様化し てきており，ユーザーニーズに合わせたシステム設計を展開していく．またMPEG に準拠したコーデックにいち早く取

り組んできたので，その技術を生かして，放送用，通信用のエンコーダ，デコーダ機器の事業化を推進する.

\section{5. 電話機事業等}

デー夕通信，映像通信にも発展可能な PHS を立ち上げている。またデー夕放送応用として産経新聞社等と共同して (株)電子新聞を設立, 端末機器事業と共に新聞サービス事業にもトライしている.

(1996 年 10 月 2 日受付) 


\section{映像情報メディア学会への期待}

近年, 映像情報産業において急速な状況変化が起こり, マル チメディア化の進展, インターネットの急速な普及, 家庭等に おけるマルチメディアパソコンをプラットホームとする情報化 が進展している，特に，地域間や国際間の距離的・時間特な制 限をなくし，映像やデータ音声など幅広い形のコミュニケーシ ヨンとして国境を越え, 異言語間の障壁を乗り越えて往き交う 情報受発信とマルチメディアコンテントとしての映像の果たす 役割には大きな期待が寄せられている.

かたわら，ディジタルコンテント制作の中核技術となっているのは，CG 技術（コンピュータグラフィックス）と動画 再生技術である。これを実現したのが CPU の高速化, CD-ROM ドライブの普及, 画像処理チップの採用である.この ような技術ベースにポリゴンやテクスチャマッピングという画像処理が実現されている. 最近のフルCG の映画や 3 次元 CG ゲームの登場などに見られるように, これらは特に映画やゲーム等, エンターティメント系のコンテント制作におい て, 非常に重要な技術となっている。 また，今後の考えられる新しい技術としてVR(Virtual Reality：仮想現実感), AR (Augmented Reality：拡張現実感）など, 人間の感覚を増強する技術の研究も進んでおり, 近い将来このような技 術等が, コンテントクリエータにとって久かせない多彩な表現形態を可能とし, 既存の映像とともに社会的に適合しつつ 今後一層の進展が期待される.

こうした中で, (社)テレビジョン学会が(社)映像情報メディア学会に発展改称されることは誠に時宜を得たものであ り, 映像情報メディアの学術・研究のパイオニアである貴学会に対する期待はますます大きなものと確信している. 通商 産業省といたしましても, こうしたマルチメディア時代に向けてコンテント制作の振興を重要施策のひとつとして位置づ け, インフラの整備, 人材育成を図ることとしている. また, こうしたディジタル技術を応用し, 文化遺産・伝統文化に 根ざしたコンテントの蓄積(ディジタルアーカイブ構想)などにも積極的に取り組んでいるところである.

最後になりますが，貴学会が映像情報メディアの発展のために寄与されますことを祈念致します。（1996 年11月7日受付）

\section{わが社の映像情報メディア戦略}

新たな「映像情報メディア学会」の発足, 誠におめでとうご さいます。テレビジョンに深く係わり育てられた当社抢よび私 にとって, 深い感概と時の流れを痛感する日々であり,この英 断を推進された高木前会長様, 金子会長様はじめ理事の方々の ご労苦に深い感謝の念を捧げます。

私は去る 6 月に米国のゲティスバーグを再訪し，感激を新た にした. 1863 年 7 月に南北戦争の激戦が闘われ, その 4 力月 後にリンカーン大統領が有名なあの演説を行った記念の地であ
長 岡 良 富

松下電器産業株式会社 取締役 映像音響情報技術担当 兼 AVC 商品開発研究所 所長

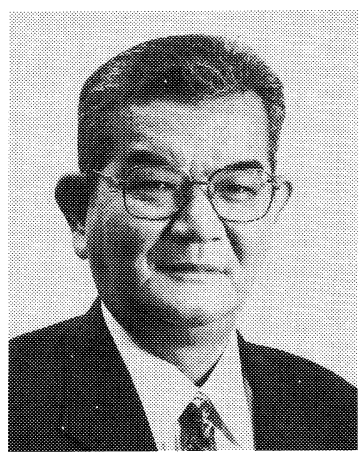

る。「人民の，人民による，人民のための政治…」で有名な， 272 語の短い，しかし歴史に残る演説がなされた地であ る.私に同行してくれた米国人所長は, 米国ではそのフレーズよりも演説の冒頭の部分, 「87 年前, 我われの父祖たち は，この大陸に新しい国家を打ち立てた，その国は自由の理念により身ごもり，すべての人間は平等につくられたという 理念に捧げられた」リの方が有名であり, 小学校でも繰り返し教えていると話してくれた. 私には新しい発見であり, 米 国建国の崇高な理念を再確認する機会となった，当社も創業以来, 社会への貢献を究極の目標とし, 本年で 78 周年を迎 えた. 米国が今後も自由と平等を高く揭げて行くように, 当社も社会への貢献を更に高めるべく努力を続けて行くことに なる。

今世紀末から来世紀にかけて, 世界はさらに狭くなり, 豊かさの輪が大きく広まっていく一方, 資源エネルギーや環境 などの深刻な問題の解決を迫られることになる。ディジタル技術や映像情報をコアとしたマルチメディア技術は, エネル ギー消費を削減しつつ人びとの知的欲求や心の交流を豊かにする有力手段として, 重要性を増して行く. “Heartful Digital Friendship”こそが, 当社の映像情報メディア戦略を表わすのに最もふさわしい言葉だと考えている.

1）ゲリー・ウィルズ著, 北沢栄訳：「リンカーンの三分間」, 共同通信社, (1995)

(1996 年 10 月 2 日受付) 


\section{ハイビジョンを中心とした ISDB への展開}

昨年のアトランタオリンピック，NHK はヨーロッパの ZDF と共同で，276 時間に及ぶ世界初の本格的なハイビジョ ン中継を行った，広い競技場全体を包む感動を美しい映像で描 き切ったのはまだ記憶に新しい. 白黒からカラーへ, そしてワ イドなハイビジョンへと,テレビはその場の臨場感を再現する ことを目指して発展してきた。ハイビジョンの映像は 21 世紀 のテレビの主流と考える.

一方，ディジタル技術は放送の世界にも様々な進展をもたら

長谷川 豊 明

日本放送協会

専務理事・技師長

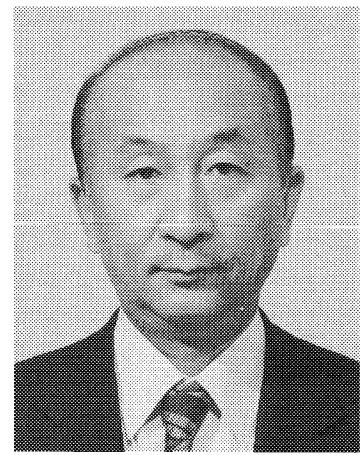

す．それは大別すると，多チャンネル化，高画質化，高機能化の 3 点である. 多チャンネル化はすでに民間の事業者によ って実用化されているが，NHK が目指す方向は八イビジョンによる高画質化とその画面を最大限活かした ISDBによる 高機能化である. ISDB は, 高画質・高音質のハイビジョンの映像に加え, 音声, 文字, 図形, データなど各種の情報を ディジタル化して，1つのチャンネルで伝送するものである．ISDB が実現すると，視聴者は受信した番組や情報をサー バに蓄え，好きな時に自由に選択し組合せて見ることができる。また，電話回線などを利用してこれまでの放送では実現 できなかったインタラクティブ性と双方向性を持ち, 視聴者の必要に応じて詳しい情報を提供したり, 参加することも可 能となる. 最近のハイビジョン受信機の普及はめざましいものがあり，価格も数年前の約 10 分の 1 となっている.今後 も八イビジョン放送の充実・拡充に努め, 八イビジョン受信機が各家庭に広がっていくことが ISDB 実現へ向けての基 盤のひとつとして重要である.

社会がますます多様複雑になる中，家庭の団らんや心を癒す放送への期待も一層大きくなると考元れれるこれらの状 況を見据え，21 世紀に向けて，映像情報を「あまねく」正確，迅速に伝送するとともに，視聴者の「心」を大切にする メディアとして, 高画質なハイビジョンを中心に ISDBへの展開を図っていきたい.

(1996 年 10 月 4 日受付)

\section{映像メディアの知的処理をめざして 一先導的かつ基盤的な研究開発の推進一}

通信総合研究所では, 21 世紀の高度情報通信社会に向け, 平成 7 年度から「情報通信基盤技術に関する基礎的・汎用的技 術の研究開発」を開始し, 超高速ネットワーク技術, ユニバー サル端末技術および高度情報資源伝送蓄積技術の 3 分野につい て, 産・学・官の連携・共同体制で研究開発を推進している. これらのうち「高度情報資源伝送蓄積技術に関する研究」で は, 映像情報を利用した今後の情報通信ニーズの高度化や多様

古 濱 洋 治 郵政省通信総合研究所 所長

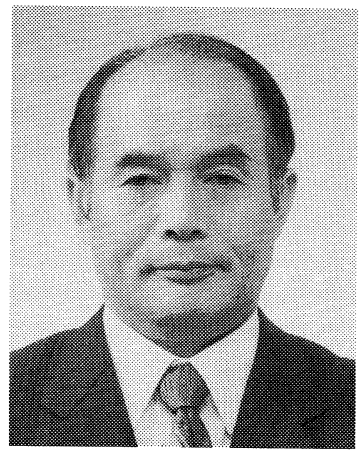
化に応えるため, 映像情報メディアを中核としたより高度な情 報資源の生成, 蓄積, 検索, 処理, 圧縮, 伝送, 表示に関する基盤技術の確立を目指し, 以下の 3 つ研究を進めている.

第 1 は, 医療, 教育, 学術分野における映像の再現性やリアル化のため, 高精細化・高画質化, ならびに通信, 放送, 蓄積等のさまざまな映像メディアの統合化を可能にする, 八イビジョンの 4 倍以上の超高精細映像の生成・入力技術と符 号化技術の研究である.また, 高品質かつ 3 次元的な表示により, 病気診断や手術計画を支援する医用画像処理・表示技 術の研究である。第 2 は, 個人により異なる感性や曖昧, 類似な検索要求からでも, 対話や知識, 学習を通して目的とす る映像を誤りなく検索できる，人にやさしい知的映像検索技術の研究である。また，映像検索の手掛かりとなるインデッ クスを映像から自動的に抽出したり, 映像の内容を構造化して領域毎に符号化したり部品化して蓄積する, 映像の内容や 意味に立ちいった知的映像処理技術の研究である. 第 3 は, インターネットに代表される広域に分散した膨大かつさまざ まなマルチメディア情報の中から必要となる情報の探索・検索や, 検索した映像を所望の映像品質, 伝送品質, さらには 端末の表示能力に応じてフレキシブルに伝送する知的映像伝送技術の研究である.

我々を取り巻く情報環境が激変する流れの中で, 映像メディアをより使い勝手の良い便利なメディアへと進化させるた め, 先導的かつ基盤的な研究開発を積極的に推進していきたい.

(1996 年 9 月 27 日受付) 


\section{システムの高度化・才能の集約・スキルの向上}

1. 現行地上波放送の強化 メディアの多様化が進展する 中で, 映像メディアの中核としてのテレビジョンのパワー アップが, 他のメディア対応の前提となることはいうまで もない。地上波テレビジョンの経営資源をいかに活用する か，そこからすべては始まる。

2. 国際的視点の確立 電波に国境はない。 そのうえ, 情 報産業は一国の枠を越え, 世界的規模で展開しつつある. 日本の放送はドメスティックな産業として高度な発達を遂 げたが，今後は国際的にどう展開するかが課題である。

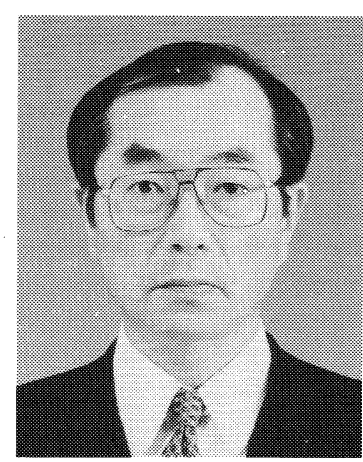

3. 多メディア多チャンネル状況への対応＼cjkstart地上波テレビジョンの総合編成をベースに, より付加価值の高いサービ スを開発することが重要である.エンタティメント系では, 高精細性も重要な付加価値となる. 衛星, オンライン, パッケージなど，あらゆるメディアを対象とする．

4. システムの高度化 近い将来, 特に情報系ソフトにおいては, 地上波という枠を越え, 収集一蓄積一配信のシス テムを高度化しフレックスなメディア対応を可能にする。

5. 才能の集約とスキルの向上 映像メディアでは, 広告であれ有料であれ, より多くの視聴者の支持が必要であ り，そのための才能を集約しなければならない.また，その才能を映像として具体化するためのプロとしてのスキル の向上が不可欠である。

6. 技術的進歩への対応テレビジョンが技術と密接不可分なメディアであることはいうまでもない. ある技術開発 がどの時点で社会的に認知されるか，「技術の社会的展開」に参画しなければならない.

以上の課題に対応することで, 次世代のメディアの本線を見極め, テレビジョンが映像メディアの中核であり続けるこ とが最大のテーマである。

(1996 年 9 月 30 日受付)

\section{Here, The Future}

「Here, The Future」末来を今ここにひきよせる。これは, 平成 8 年 9 月から採用している日立の情報・エレクトロニクス 事業分野における全社の新スローガンである.はるか遠い未来 にしか実現できないのではないかと誰もが思っていた様々なこ とが, 次から次へと現実のものとなりはじめたら, どんなに素 晴しい毎日が訪れることであろうか.

私たちのこれからの毎日に, 無限の可能性を与えてくれるマ ルチメディア、その基本は, 動画(映像), 静止画像, 音声, 文

三木 義 照 株式会社日立製作所 常務取締役

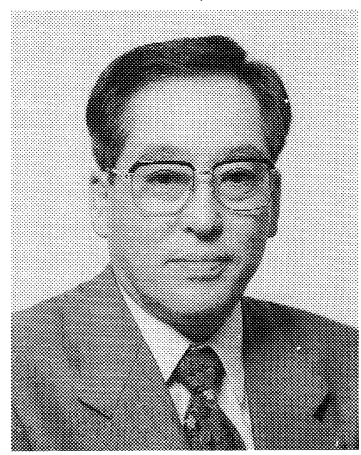

字など，それぞれに異なる種類の情報を扱ってきた様々なメディア；テレビ，コンピュータ，パッケージメディア(CDROM)，通信ネットワーク(電話など) を有機的に結びあわせることである. 中でも，動画情報をいかに効率良く加工・伝 送できるようにするかが最も大きな技術課題であった，日立は，世界初の MPEC-1 規格に準拠する CODEC 用 LSI の 1 チップ化に成功．これにより，世界標準の MPEG 動画像圧縮技術を応用した商品を身近なものにできる。

日立では, ダ・ヴィンチ計画を 3 年前からスタートさせている。これは, 新しい商品の開発と事業化をスピードアップ させるための制度で, プロジェクトリーダはダ・ヴィンチと命名され, 開発・製造・販売を一貫して任される。お茶の間 で手軽に楽しめるインターディスク, インターネットプレーヤ, 新マルチウィンドウ, MPEGカメラ, IRD, DVD, DVHS, PDP 等の新商品をダ・ヴィンチ計画で開発している。この中でも戦略的な新商品は全社プロジェクトにて推進 し，マンパワーや資金等のリソースを重点投入し大型開発の早期実現を図っている。また，これらの商品を実現する上で 不可欠のキーデバイスである MPEG CODEC 用 LSI, SuperH（RISC engine）, DVD 用光ピックアップ, 広視野角スー パーTFT 等を戦略部品として活用し，「21 世紀のディジタル映像力」を目指した魅力ある商品開発を加速している.

(1996 年 10 月 17 日受付) 


\section{グローバルマルチメディアサービスに向かって}

先のアトランタオリンピックでは, 現行テレビおよびハイビ ジョンテレビの国際中継とも, 従来のアナログ衛星伝送方式に 代わって KDD 独自の高品質ディジタル符号化方式により，大 容量光海底ケーブル (TPC-5)を通して行われた。いよよデ イジタル映像伝送の時代である. 今後も放送の多チャンネル化 などにより映像伝送ニーズはますます増加し，多様化していく であろう。それに応えるため, ディジタル映像伝送技術の開発 には一層力を入れていく. 伝送メディアとしては, 低遅延伝送

村 谷 拓 郎 国際電信電話株式会社 代表取締役 副社長

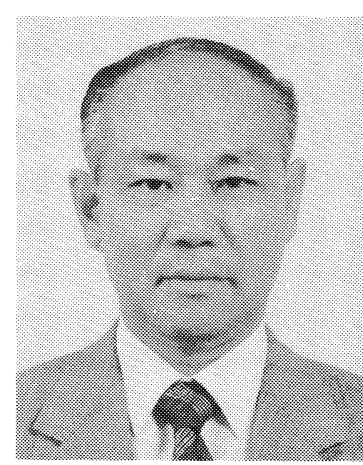

ができる光海底ケーブルと, 機動性や多地点への映像配信を特長とする衛星を状況に応じて使い分け，ユーザのニーズに 的確に応えていきたい. またテレビ報道の求める,「いつでも, ぞことでも可能な映像伝送サービス」に近づくために, 国際的な連携の強化, より進んだサービス予約システムや映像伝送ネットワーク等の開発に務めていく.インマルサット 衛星等により, 通信インフラのない地域からの映像伝送を可能にし, テレビ報道に新しい道を開いた映像蓄積伝送システ ムVAST-p シリーズの開発もこの一環である。

1997 年には日米間のインターネット通信量は電話を越えることが確実となった。まさにマルチメディア時代の到来で ある.マルチメディアサービスに扔いて, 映像は非常に重要な位置を占める. 光ケーブルの採用等により伝送容量が大幅 に増加していくとしても, 効率的で高品質のディジタル映像伝送技術が多くのマルチメディアサービスを成立させる鍵と なるであろう. KDD はインターネットをマルチメディアサービスの重要なインフラととらえサービスを開始している. これをさらにより身近な CATV 等を利用して拡張し, その上で実績のある映像符号化技術をベースに, マルチメディア 情報検索やオンデマンド映像配信等のサービスの提供も目指したい.

当面は, テレビ映像伝送サービスとマルチメディアサービスは別個のものであるが, 将来的には通信インフラの点でも 映像コンテンツの点でも重なり合ってくると考えられる. 広く, グローバルマルチメディアサービスとして, 高品質な映 像情報の流通促進に一層努力していきたい.

(1996 年 11 月 7 日受付)

\section{ネットワーク時代の映像情報メディア戦略}

昨今の映像情報を取り巻く技術の変化汅は, 目を見張るもの がある．これは，スタンドアローンの機器の無機的な集合から ネットワークで有機的に結合された多種多様の情報機器への変 化と, 有形の情報媒体からネットワーク上の無形の情報への変 化であり,一言でいうといわゆるネットワーク時代の到来である。

現時点での当社のコア技術は, ディスプレイ/ストレージ/画 像処理などの AV 技術であるが, ネットワーク時代の映像情 報関連技術にも， $\mathrm{A} V$ 技術/ノウハウを生かしたアプローチが

森尾稔

ソニ一株式会社

代表取締役 副社長

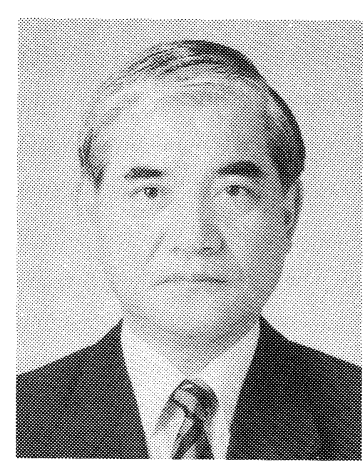

重要かつ必要不可欠と考えている. ディスプレイは情報の空であり, 非常に重要なマンマシンインタフェースとして捉え ている。また，高度映像情報を取り扱う上では更なる高密度記録が必要になる．AVで培った画像処理技術は，今後共そ の重要性は增すばかりであろう。一方, 今後はこれら AV 技術の強化に加え, IT 関連技術やネットワーク関連技術の開 発にも注力していく.

今後数年の間, 情報関連業界(情報サービス業界/情報機器業界) と家電業界が共に目指すターゲットのひとつは, 家庭 内における新規アプリケーションの創造であることは衆目の一致するところであろう. 当社はこれを, AV 機器と PCの 融合といった単純な端末技術の変化のみならず, 映像情報自体の変化を伴う事象と捉えている.すなおちネットワーク技 術/ディジタル技術によって, 映像コンテンツの在り方/捉え方が根本的に変化し, それに合わせた技術/事業を構築して いくことが必要となると考える.

当社は, AV 技術の展開と変容する映像情報への先駆的対応の両面から, ネットワーク時代の映像情報事業をリードし ていく.

(1996 年 9 月 26 日受付) 


\section{BIGLOBE を核とした映像情報提供サービス}

映像情報とは，さまざまなディスプレイ（スクリーンを含 む）に表示される情報,メディアとはその映像情報を伝達する ものと定義する，NECでは，テレビ，通信衛星，CATV，衛 星放送, テレビ会議, 高精細度テレビ, MOD（マルチメディ アオンデマンド）など，映像情報メディアの開発をたえず顧客 価值の創造の立場で遂行してきている，また，映像情報を表示 するディスプレイもパソコン用に高精細のカラー液晶表示のも

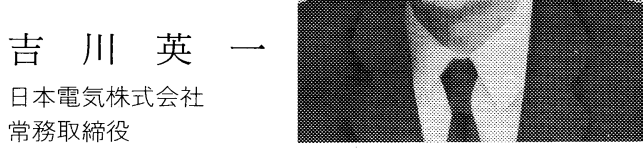

のを開発し続けている。このように，NEC は映像を使った情報メディアの重要性を認識しながら事業を展開しているが， 本稿では，映像情報をインターネット上で活用するという視点での戦略を述べる.

現在, マルチメディア事業の核として, BIGLOBEサービスを展開している.これは, インターネット接続サービス, パソコン通信サービス, 情報提供サービスを融合させた NEC 独自のものである. 情報提供サービスでは, Cyber Plaza にオンラインマガジン, オンラインショッピング, インターネット放送局, プロ野球中継, オンライブなど多彩なコンテ ンツを揃え，会員を急速に増やしている。

インターネット放送局は, 北海道に 3 局, 高知県に 1 局開局し（1996 年 9 月現在）, 今後日本全国に設置していく. 日 本の美しい自然景観を 24 時間ズームアップで，しかも広い範囲をフォーカスできるように工夫しているので, BIGLOBE 会員の人気も急上昇中である。この景観放送纪続く番組制作もりリースさせる計画である.

プロ野球のファンのためのインターネット野球中継も好評であるが, まだ映像伝達に課題がある。しかし, アバターや 知的符号化といったニューテクノロジーや 3 次元 CG を活用することによって, インタラクティブメディアの特長を生か した映像情報を創り出すことができる.

このマルチメディアネットワークサービスの基本は，面白く，つながりやすく，安く，さらに美しくというのが普及の ための原則である，そのために，面白いコンテンツの製作提供，アクセスポイントの拡充，利用料金の低減を推進してい く必要がある.NECは，マルチメディアネットワークが教育，医療，宣伝広告，安全危機管理の分野抢よび距離を越元 た人々との触れ合いに貢献することを確信し，映像情報メディアの開発に取り組んでいく．

(1996 年 10 月 14 日受付) 